\title{
Issues Related to Accounting Education for NFPs in the U.S.
}

\author{
Fuminobu Mizutani \\ College of Economics, Kanto Gakuin University, Yokohama, Japan \\ Email: fuminobu@kanto-gakuin.ac.jp
}

Received 18 November 2015; accepted 8 January 2016; published 11 January 2016

Copyright (C) 2016 by author and Scientific Research Publishing Inc.

This work is licensed under the Creative Commons Attribution International License (CC BY).

http://creativecommons.org/licenses/by/4.0/

(c) (i) Open Access

\begin{abstract}
There have been no efforts to organize existing works about accounting education for NFPs. This paper is an article reviewing existing works published in the 21st century. There is a sufficient volume of cases to use the case method. Some of the existing works were about active learning (mainly service learning). Some existing works can be used to improve lectures. Some existing works can help faculty members to design their curriculums. However, some issues still remain and these issues should be resolved in the future. As a whole, the problem of existing works is lack of sufficient concerns about other academic areas. Some of future works are hoped to be more interdisciplinary.
\end{abstract}

Keywords

NFPs, Case Method, Active Learning, Service Learning, Curriculum Design

\section{Introduction}

In recent years, research related to not-for-profit (NFP) accounting is evolving in many countries. As part of this evolution, research related to accounting education for NFPs is also changing. NFPs have an important role in the U.S. alongside profit-oriented entities and government agencies, and the U.S. is a developed country with extensive research and practice related to accounting for NFPs. There is a large volume of existing works in the U.S., and each research project is of good quality. There was a special issue of Journal of Accounting Education in 2013 that played a particularly strong role in solidifying the body of existing works. The title of this issue was “Special Issue on Governmental and Not-for-Profit Accounting Education” [1]. This issue contained five academic papers related to accounting for NPFs: [2]-[6].

However, there are no efforts to organize these existing works, probably because such efforts need organized knowledge of pedagogy besides accounting knowledge. This paper is a review of the existing works published 
in the 21st century. This paper attempts to organize existing works and put together their contributions to research and education. The common characteristic of existing works in the 21st century is that they aimed to contribute not only to constructing theories but also to directly or indirectly improving educational practice. Thus, the topics in the next section are set up along with concepts related to educational practice. After that, this paper will identify issues that scholars should research more thoroughly. In this way, this paper aims to promote accounting education research for NFPs and evolving educational practice.

\section{Contributions of Existing Works}

\subsection{Cases}

In one teaching method, faculty members have students objectively read case reports and then act as case facilitators, asking students case questions related to them. This educational method is called the case method.

About half of the existing works about accounting for NFPs in the U.S. are cases. [3] [4] [7]-[10] are all examples. The reason why cases comprise such a large ratio of the existing works in the U.S. seems to be that the case method is the preferred educational method for courses related to business administration, and there is a great deal of need for cases to use for these purposes at American universities.

Cases which are mentioned in existing works have variations. Most cases are about actual events, and one case found in my research for this paper was fiction inspired by actual events. Some cases are long and some cases are short. Not all case questions are about accounting in general but some case questions are specialized and related to accounting for NFPs. Not all cases are about scandals. Some are about accounting in normal situation or liquidation events. There is even a unique case which is about an NFP that provides volunteer accounting services to other NFPs. It seems like the variations in these cases are related to the different educational purposes of the various courses that use them.

There are a lot of cases about accounting for NFPs in the U.S., and these cases are helpful for courses that use the case method.

\subsection{Active Learning}

There are some existing works about educational methods particular to accounting for NFPs, though the case method is commonly used in a variety of courses related to business management. Because these existing works are about educational methods, the form they take is sometimes not really an article, but instead resembles teaching notes. These educational methods are about objective active learning.

Education methods related to services like volunteering and academic learning are called service learning. Service learning is one type of experiential learning. Although Christian universities tend to like service learning, other types of universities incorporate it into their curriculums as well. [5] explains an innovative service learning project called "Philanthropy Project." This "Philanthropy Project" was used at two universities in the U.S. and won the 2011 Howard The all Innovation in Accounting Education award from the Canadian Academic Accounting Association. "Philanthropy Project" also received an honorable mention in Innovation in Accounting Education from the American Accounting Association in 2009. "Philanthropy Project" was an educational project in which students selected one NFP from a list of several NFPs and made a donation to it. These donations were real, and not mere fiction.

Internship is also one type of experiential learning. [11] explains an internship program called "Auditing Internship Program”. This "Auditing Internship Program” was used at Salisbury University. In the "Auditing Internship Program”, students took part in auditing NFPs. The "Auditing Internship Program” got good evaluations from partners in accounting firms. [12] explains the experiential learning at Drury University which was actually a volunteering activity by students rather than an internship. In this program, students in governmental or nonprofit accounting courses went to NFPs (such as churches) and participated in accounting procedures such as drafting financial statements. This program was also matched with the needs of NFPs. The students participated in activities the NFPs could use their assistance with. After the program was complete, the students gave feedback to the managers of the NFPs. This service learning at Drury University got good responses from both sides: both the NFPs and the students.

[6] explains another type of active learning that differs from service learning. This type of active learning is 
called self-directed learning. The program discussed in [6] had students select an organization and interview the organization about their budgetary processes. The course in which this program was introduced emphasized governmental accounting, so most students interviewed governmental organizations. However, some students interviewed NFPs. [6] did not use a question list specifically designed for NFPs. However, there are differences in budgetary processes between government organizations and NFPs because government organizations can depend on revenue from taxes and NFPs cannot. One objective of this project was to get students thinking about their own careers. Even though NFPs have less presence than profit-oriented entities and government organizations in the U.S, students who interviewed NFPs seemed to be considering working for them in the future.

The universities that utilized these educational methods achieved great educational results, but these programs require sufficient organization to succeed.

\subsection{Lecturing}

Lecturing remains popular today even though it was described as an antiquated educational method by a famous pedagogical textbook [13]. Some existing research articles referred to accounting for NFPs specifically. Faculty members can use these kinds of articles to deliver more effective lectures. Usually, these kinds of articles are intended for educational uses, but of course faculty member can also use other papers as lecture material.

[14] discusses the creation of the Not-for-Profit Advisory Committee (NAC) by the Financial Accounting Standards Board (FASB) in 2009. [14] also briefly discusses curriculum design issues, such as the issue of which course should be responsible for teaching accounting for NFPs.

[15] contains proposals to the FASB to improve the terminology of the Statements of Financial Accounting Standards (SFAS) for NFPs in order to promote improved student understanding. For example, [15] proposes that the FASB should change the name of net assets from "net assets" to "equity", the same terminology used for profit-oriented entities. [15] does not see accounting standards as a higher priority than education, but instead tries to bring a pedagogical perspective to accounting standards setting. This perspective is not an odd idea in the U.S. considering the fact that the Statement of Financial Accounting Concepts (SFAC) No. 4 ([16]) regards students as a category of users of financial statements, although this may differ from the way other countries think of students.

\subsection{Curriculum Design}

[17] explains curriculum design for the general management of NFPs course at Providence College. [17] Was published in an accounting journal and refers to accounting quite a bit. When Providence College committed to this curriculum design, the university was aware that managers of NFPs have a lot of confidence in their financial management skills and want to acquire fundraising skills. Based on this knowledge, Province College designed 2 of the 3 courses in NFP management with various accounting skills included as course objectives. The names of these courses were "Management in Not-for-Profit Organizations" and "Project Seminar in Not-forProfit Organizations". The "Management in Not-for-Profit Organization" course put especially strong emphasis on financial analysis skills.

It is appropriate that there is an existing work related to accounting education for NFPs for MBA education. [8] deals with this topic.

The only existing work which mentioned Master of Public Administration (MPA) courses is [18], and this work was not a normal article but actually an introductory article for a symposium. One thing [18] mentioned was the fact that Northern Illinois University established a course called "Accounting for Public Administration". MPAs can contribute not only to management of governmental organizations but also to management of NFPs, according to the PA Times [19]. However, remarks on MPA education in [18] were related to governmental accounting rather than accounting for NFPs, because [18] was published in a journal of governmental accounting. Even though the title of this symposium was "The Evolution of Governmental and Nonprofit Accounting Education," there was only one article from the symposium dealing with NPAs, and the article was [17]. This symposium did not have a strong focus on accounting education for NFPs as compared to special issues related to governmental and not-for-profit accounting education.

Table 1 shows the number of existing works about every type of contents. 
Table 1. The number of existing works.

\begin{tabular}{cc|}
\hline Content & Number \\
\hline Case & 6 \\
Active Learning & 4 \\
Lecturing & 2 \\
Curriculum Design & 2 \\
\hline
\end{tabular}

\section{Issues for the Future}

\subsection{Cases}

There are no cases about management accounting for NFPs in the existing works, though there are many cases about financial accounting and cases related to both financial accounting and management accounting. In practice, management accounting is important for NFPs, and it is just as important as it is for profit-oriented entities. Management accounting education is especially important when universities aim to educate students who will become management or employees at NFPs.

The typical academic area in which the case method is most effective is management, 350 cases are written per year only by Harvard Business School (HBS) [20]. Management is more related to management accounting than to financial accounting. The reason why there are no cases of management accounting in spite of this fact seems to be that case writing for management accounting requires scholarly research methods such as interviews which impose heavier burdens than case writing for financial accounting. For this reason, scholars seem to be avoiding management accounting case writing. However, there is theoretical research about management accounting for NFPs such as [21] and new management accounting methods for NFPs have been proposed such as the public value scorecard [22]. Therefore, if scholars are willing to take on the additional burdens, they can write management accounting cases referring to this theoretical research and the proposed new management accounting methods.

\subsection{Active Learning}

An issue related to active learning can also be considered an issue related to volunteering. NFPs are more likely than governmental organization to accept volunteers, considering from the fact that according to [23] the type of organizations for which most frequently the volunteers worked the most hours during 2014 was religious organizations all of which in the U.S. are NFPs. [23] shows this percentage as 33.3. There are more locations to research the methods of volunteering related to accounting in NFPs and accounting education, although [12] already investigated these topics. [24] is an article that effectively relates volunteering to accounting education. [24] explains an educational program at universities that has students volunteer at the Internal Revenue Service (IRS) as a service learning project. This program was called Volunteer Income Tax Assistance (VITA). The client list for VITA seems to include almost no NFPs.

However, it is notable that one university contacted several churches that refused to participate. [24] Did not explicitly state which educational level students were, but we can infer that the students were probably undergraduate students. Because NFPs must submit a special type of report called Form 990 to the IRS, churches may have felt that undergraduate students did not have sufficient knowledge to assist in submitting Form 990. Therefore, if universities introduce VITA to education programs for graduate students, NFPs such as churches might accept these students as volunteers.

Regarding service learning, there is a gap between pedagogy and accounting theory. [25] Is a pedagogical piece, and it referred to accounting for NFPs. But there is a gap between [25] and other existing works by accounting scholars. The first topics [25] listed which students of accounting can do as service learning projects were related to developing accounting systems for NFPs. In [25], these topics were also near the top of the list for all academic areas because [25] ordered academic areas alphabetically. However, the existing works written by accounting scholars discussed development of accounting systems for NFPs. Because developing accounting systems for NFPs requires specialized knowledge, in order to fill this gap accounting scholars' research was almost entirely limited to service learning for MBA course students or MPA course students. 
Because there may be universities practicing development of accounting systems for NFPs as a form of service learning in the U.S, filling this gap is a good way for accounting scholars to explore educational practice. In recent years, interdisciplinary research is being promoted in English speaking countries. The impact factor in 2014 of Accounting, Organizations and Society, the typical interdisciplinary journal, was higher than 1.67 [26]. Filling this gap between pedagogy and accounting theory fulfills social needs for interdisciplinary research.

\subsection{Lecturing}

There is a lack of syllabi which can be models for lecturing. There were no existing works about lecturing that provided true syllabi or proposed syllabi, though some existing works which were not about lecturing provided syllabi. We can know the importance of the syllabi from the fact that 6 of 8 Ivy League universities publishes guides to write syllabi on their own websites. As individual work, it may be proper to avoid providing syllabi in order to prevent prematurely decide a main theme. However, when we consider the common knowledge of accounting academies, we need information about lecturing syllabi. These will regulate the content of lectures for each course with consideration for the types of courses and educational steps. If scholars provide syllabi which consider combinations of types of courses and educational steps, such work will help faculty members to deliver effective lectures.

Although [12] is about active learning, [12] also referred to the lack of textbooks covering accounting topics for NFPs. This is a serious detriment for lecturing. In American universities, several textbooks about accounting for profit-oriented entities occupy dominant position nationwide. For example, the number of intermediate accounting textbooks which were surveyed by [27] supported from the Deloitte Foundation is merely 3. The appearance of a dominant accounting textbook that covers NFP accounting topics would help university faculty deliver standardized lectures throughout the country.

\subsection{Curriculum Design}

By nature, MPA course curriculums are hoped to include education about accounting for NFPs, because accounting is an academic area which is difficult to master through practical experience alone. This necessity of accounting education in higher educational institutions can be suggested from the statistics by a NFP in Bethlehem that shows that $50.6 \%$ of employers in the U.S. want students to earn degrees in accounting [28]. In order to provide future managers to NFPs, research regarding what curriculums are appropriate for MPA course students and can teach them what they need to know about NFP accounting is important.

All educational purposes which were listed by [11] are about accounting in general and [11] did not list any educational purposes specialized to NFPs. Students who join active learning projects related to accounting for NFPs will acquire accounting knowledge more or less specialized to NFPs from their experiences. However, in order to deliver a well-planned course, faculty members should consider whether educational purposes they are aiming for are specialized to NFPs or not.

Most existing works listed educational purposes specialized to NFPs. If most faculty members have educational purposes specialized to NFPs and also educational practice related to accounting for NFPs in mind, there is little need for them to consider the issue mentioned above. However, the core of modern accounting education is about profit-oriented entities, as we can know from the [29] which shows that only 22 cases of more than 400 cases published in Issues in Accounting Education were about governmental or NFP accounting. Thus in educational practice, it seems that the main educational purposes are often related to general accounting even when faculty members have students learning accounting for NFPs. After all, scholars need to consider whether courses related to accounting for NFPs should aim for educational purposes specialized to NFPs or not.

\section{Conclusion}

First, this review article organized the existing works about accounting education for NFPs. Next, this article made some proposals regarding creating cases related to management accounting, bridging the gap between pedagogy and accounting theory, providing syllabi for use with lectures, and researching how to educate MPA students. As a whole the problem of existing works is lack of sufficient concerns about other academic areas, though existing works are appropriate when we see them as separate works. However, existing works succeeded to delve into the academic area of accounting itself. Based on the contributions to the field made by the existing 
works, NFP accounting education research in the U.S. will likely continue in the future. Some of future works are hoped to be more interdisciplinary.

\section{References}

[1] Stout, D.E. (2013) Special Issue on Governmental and Not-for-Profit Accounting Education Vol. 31, Issue 3 (2013). Journal of Accounting Education, 31, 213-214. http://dx.doi.org/10.1016/j.jaccedu.2013.06.003

[2] Gordon, T.P. (2013) Not-for-Profit Accounting in a Changing World of Standard Setting: What Professors and Students Need to Know. Journal of Accounting Education, 31, 232-243. http://dx.doi.org/10.1016/j.jaccedu.2013.06.005

[3] Clemenson, B. and Sellers, R.D. (2013) Hull House: An Autopsy of Not-for-Profit Financial Accountability. Journal of Accounting Education, 31, 252-293. http://dx.doi.org/10.1016/j.jaccedu.2013.07.002

[4] Neely, D.G. and Tinkelman, D. (2013) The Whip Cancer Walk: A Case of Real Earnings Management in the Nonprofit Sector. Journal of Accounting Education, 31, 294-309. http://dx.doi.org/10.1016/j.jaccedu.2013.06.004

[5] Huber, M.M. and Mafi, S.L. (2013) Education par Excellence: Developing Personal Competencies and Character through Philanthropy-Based Education. Journal of Accounting Education, 31, 310-332. http://dx.doi.org/10.1016/j.jaccedu.2013.07.001

[6] Killan, L. (2013) The Budgetary Interview: Intentional Learning for Students in Governmental and Non-Profit Accounting. Journal of Accounting Education, 31, 350-362. http://dx.doi.org/10.1016/j.jaccedu.2013.04.001

[7] Nicholls, C.M. and Mastrolia, S.A. (2015) Second Chance Homeless Shelter: A Fraud Exercise for Introductory and Survey Courses in Accounting. Advances in Accounting Education: Teaching and Curriculum Innovation, 17, 1-24. http://dx.doi.org/10.1108/S1085-462220150000017001

[8] Ruhl, J.M. and Smith, O.M. (2012) A Perfect Storm: A Case in Nonprofit Financial Reporting. Issues in Accounting Education, 27, 819-836. http://dx.doi.org/10.2308/iace-50079

[9] Churyk, N.T., Yu, S.(C.) and Blumstein, H. (2011) Accountants' Relief Foundation (ARF): A Not-for-Profit Case Examining Contribution Receipts and Distributions. Journal of Accounting Education, 29, 60-85. http://dx.doi.org/10.1016/j.jaccedu.2011.10.001

[10] Bremser, W.G. (2001) Accountants for the Public Interest: Strategy Implementation and Performance Measurement for a Nonprofit Organization. Journal of Accounting Education, 19, 75-86. http://dx.doi.org/10.1016/S0748-5751(01)00009-4

[11] Dombrowski, R.F., Smith, K.J. and Wood, B.G. (2013) Bridging the Education-Practice Divide: The Salisbury University Auditing Internship Program. Journal of Accounting Education, 31, 84-106. http://dx.doi.org/10.1016/j.jaccedu.2012.12.003

[12] Still, K. and Clayton, P.R. (2004) Utilizing Service-Learning in Accounting Programs. Issues in Accounting Education, 19, 469-486. http://dx.doi.org/10.2308/iace.2004.19.4.469

[13] Brinkley, A., El-Fakahany, E.E., Dessants, B., Flamm, M., Forcey Jr., C.B., Ouellett, M.L. and Rothschild, E. (2011) The Chicago Handbook for Teachers: A Practical Guide to the College Classroom. Second Edition, University of Chicago Press, Chicago. http://dx.doi.org/10.7208/chicago/9780226075136.001.0001

[14] Gordon, T.P. (2013) Not-for-Profit Accounting in a Changing World of Standard Setting: What Professors and Students Need to Know. Journal of Accounting Education, 31, 232-243. http://dx.doi.org/10.1016/j.jaccedu.2013.06.005

[15] Aranoff, G. (2003) Improving Disclosure and Transparency in Nonprofit Accounting. Management Accounting Quarterly, 4, 15-23.

[16] FASB (1980) Statement of Financial Accounting Concepts No. 4: Objectives of Financial Reporting by Nonbusiness Organizations.

[17] Jervis, K. and Sherer, P. (2005) The Course Development Process for an Integrated Nonprofit Management Course Concentration: Business Competencies Needed for Nonprofit Careers. Journal of Public Budgeting, Accounting \& Financial Management, 17, 249-275.

[18] Kattelus, S.C., Cheng, R.H. and Engstrom, J.H. (2005) The Challenges of Cross-Disciplinary Work: Accounting and Financial Reporting for Governments and Nonprofits. Journal of Public Budgeting, Accounting \& Financial Management, 17, 152-165.

[19] What Can You Do with an MPA Degree? PA Times, October 2002, p. 16.

[20] Harvard Business School (2014) The HBS Case Method. http://www.hbs.edu/mba/academic-experience/Pages/the-hbs-case-method.aspx

[21] Anthony, R.N. and Young, D.W. (2003) Management Control in Nonprofit Organizations. 7th Edition, McGraw-Hill, Boston. 
[22] Moore, M.H. (2003) The Public Value Scorecard: A Rejoinder and Alternative to "Strategic Performing Measurement and Management Non-Profit Organizations” by Robert Kaplan.

http://www.ksghauser.harvard.edu/PDF_XLS/workingpapers/workingpaper_18.pdf

[23] Bureau of Labor Statistics (2015) Volunteering in the United States_-2014.

http://www.bls.gov/news.release/pdf/volun.pdf

[24] Strupeck, C.D. and Whitten, D. (2004) Accounting Service-Learning Experiences and the IRS Volunteer Income Tax Assistance Programme: A Teaching Note. Accounting Education, 13, 101-112. http://dx.doi.org/10.1080/0963928042000182475

[25] Watts, M.M. (2006) Service Learning. Pearson Education, Upper Saddle River.

[26] Thomson Reuter (2015) Journal Citation Reports.

[27] Fay, R.G., Brozovsky, J.A., Edmonds, J.E., Lobingier, P.G. and Hicks, S.A. (2008) Incorporating International Financial Reporting Standards (IFRS) into Intermediate Accounting. Virginia Polytechnic Institute and State University in Blacksburg, Blacksburg. https://sun.iwu.edu/ golson/Incorporating_IFRS_into_Intermediate_Accounting_v1-1.doc

[28] Adams, S. (2008) The College Degrees and Skills Employers Most Want in 2015. Forbes (Electronic Edition). http://www.forbes.com/sites/susanadams/2015/04/15/the-college-degrees-and-skills-employers-most-want-in-2015/

[29] Lipe, M.G. (2006) Using Cases Published in Issues in Accounting Education: Categories and Topics at a Glance. Issues in Accounting Education, 21, 417-430. http://dx.doi.org/10.2308/iace.2006.21.4.417 